\title{
3 全自動赤血球沈降速度測定装昷の基硉的検討
}

池野廣幸, 菅原 通, 大川共一（日本医科大第二病院）

赤血球沈降速度（血沈）湘定は, 感染や炎症の経過 の判定等に用いられ, 特に結核での活動性ならびに潜 在性疾患の在否判断において臨床的価值と共に重要な 検查として, 健康診断拉よび日常の診療で, 現在でも 重要な検査として広く行われている.

我々は簡便で短時間に情報が得られる全自動赤血球 沈降速度測定装置『VES-NA T I C』について, 基礎的㭘討（国際法との相関，同時再現性，乳び・溶 血の影響）を行いその有用性について検討した.

本装置の測定原理は，血沈管を傾斜させることによ り, 測定時間を短縮させ, 赤血球の沈降レベルを光学 電子センサーにより自動的に㜔み取るるのである. 即 ち，血沈間を傾斜すると赤血球凝集塊の形成が容易で
あること，また，血沈管の全面壁を伝わり上行する血 脽と，後面壁を下行する血球を大は血球凝集塊の抵抗 が少なく流れの分離が明確となることを応用したもの である．また，本装置の特徴として次のことが見られ た.

(1) 1 時間値が30分以内で測定可能である.

(2)検体量が $1 \mathrm{ml}$ である.

(3)基準温度が（18C）への結果補正ができる.

(4)全自動のため，手技拈よび読み取り誤差が少な い.

(5)専用血沈管（バキュテック）を使用のため生物的 污染が防止できる（完全クローズドシステム）

(6)自動摬汼によりデータ誤差が少ない。

\section{DIGITAL OSCILOSCOPE を用いた人工呼吸器 (NIF 機能) 解析の試み}

西山 毅, 大越裕幸 (戸田中央総合病院ME科), 山口 剛 (同麻酔科)

[目的〕 $\mathrm{P}_{0.1}$ 搭載ベンチレータは, 現在 2 機種あ る. 昨年私は, EVITA と CP-100の $\mathrm{P}_{0.1}$ を高速 ナログレコーダーにて比較検討した（第16回人工呼吸 学会). $P_{0.1}$ 計測では, アナログレコーダーでの限界 を痛感させられこれ以上の解析には，DIGITAL OSCILOSCOPE を用い信号補足を行い波形を再出力出 来る機器が必要と考え, DIGITAL OSCILOSCOPE 9304 A (Lecroy 社) を用いた. ADULT STAR 2000 を用いて CRT 画面上汇表示される $P_{0.1}$ 及 び $\mathrm{NIF}$ が A/D 変換される前と後を比較検討した. ま た $\mathrm{P}_{0.1}$ 及び NIF の測定ポイントについても合わせ て検討した.

[方法及び対象]女性38才肺炎 ベンチレータは ADULT STAR 2000 SIMV+PS にて呼吸管理 と なる。測定は，9304A を用いディジタルフィルター は，エンハンスド・レン゙リューション，サンブリング
分解能は, $2 \mathrm{Ks} / \mathrm{s} \triangle \mathrm{t} 100 \mathrm{~ms}$, ロールモードにて波 形補足する. ADULT STAR A/D 変換プロッセサ にバッンブプローブを接続, CPAP (PEEP $7 \mathrm{cmH}_{2} \mathrm{O}$ ) と CPAP (PEEP $\left.0 \mathrm{cmH}_{2} \mathrm{O}\right)$ の A/D 変換される前 と後の $\mathrm{P}_{0.1}$ 及び NIF を測定し合わせて計測ポイン トについても考察, 統計学的处理はマンホイットニー U-test で行った.

[結果] CPAP (PEEP 7) と CPAP (PEEP 0) を比較するとADULT STAR と 9304 A では, $9304 \mathrm{~A}$ で計測值が低目の值となって表示された。測 定ポイントの解析では， $\mathrm{P}_{0.1}$ 及び NIF の計測尗イン 卜を推察し得たと思われる.（スライド参照）

[考察] ADULT STARP 0.1 及び NIF は, 9304 $\mathrm{A}$ で取り込んだ䉓生值 $\left(\mathrm{cmH}_{2} \mathrm{O}\right.$ 換算) より高值とな ったが，臨床上相対值としては問題ないと思われる。 